\title{
Stereoselective Synthesis of the Isomers of Notoincisol A: Assigment of the Absolute Configuration of this Natural Product and Biological Evaluation
}

Lukas Rycek, ${ }^{\dagger}$ Vincenzo Ticli, ${ }^{\dagger}$ Jakob Pyszkowski, ${ }^{\ddagger}$ Simone Latkolik, ${ }^{\S}$ Xin Liu, ${ }^{\perp}$ Atanas G. Atanasov, ${ }^{\S}, \|$ Theresa Steinacher, ${ }^{\#}$ Rudolf Bauer, ${ }^{\perp} \odot$ Daniela Schuster, ${ }^{\#, I I}$ Verena M. Dirsch, ${ }^{\S}$ Michael Schnürch, ${ }^{\dagger}{ }^{\circ}$ Margot Ernst, ${ }^{*}$ and Marko D. Mihovilovic*, ${ }^{\dagger}$

${ }^{\dagger}$ Institute of Applied Synthetic Chemistry, TU Wien, Getreidemarkt 9/163-OC, 1060 Vienna, Austria

${ }^{\ddagger}$ Department of Molecular Neurosciences, Medical University of Vienna, Spitalgasse 4, 1090 Vienna, Austria

${ }^{\S}$ Department of Pharmacognosy, University of Vienna, Althanstrasse 14, 1090 Vienna, Austria

${ }^{\perp}$ Institute of Pharmaceutical Sciences, University of Graz, Universitätsplatz 4, 8010 Graz, Austria

"Institute of Genetics and Animal Breeding of the Polish Academy of Sciences, 05-552 Jastrzebiec, Poland

\#Institute of Pharmacy/Pharmaceutical Chemistry, University of Innsbruck, Innrain 80-82, 6020 Innsbruck, Austria

${ }^{\text {II } D e p a r t m e n t ~ o f ~ P h a r m a c e u t i c a l ~ a n d ~ M e d i c i n a l ~ C h e m i s t r y, ~ I n s t i t u t e ~ o f ~ P h a r m a c y, ~ P a r a c e l s u s ~ M e d i c a l ~ U n i v e r s i t y ~ S a l z b u r g, ~}$ Strubergasse 21, 5020 Salzburg, Austria

Supporting Information

ABSTRACT: The total syntheses of all stereoisomers of notoincisol A, a recently isolated natural product with potential anti-inflammatory activity, are reported. The asymmetric synthesis was conducted employing a lipase-mediated kinetic resolution, which enables easy access to all required chiral building blocks with the aim of establishing the absolute configuration of the naturally occurring isomer. This was achieved by comparison of

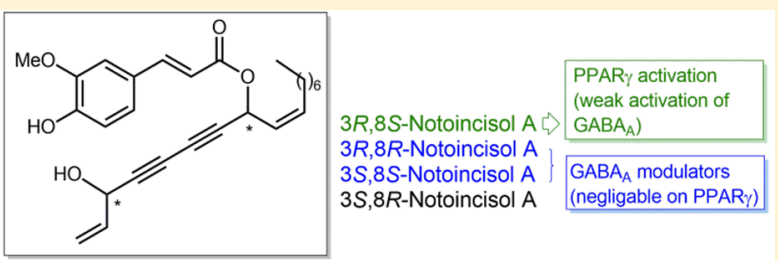
optical properties of the isolated compound with the synthetic derivatives obtained. Moreover, an assessment of the biological activity on PPAR $\gamma$ (peroxisome proliferator-activated receptor gamma) as a prominent receptor related to inflammation is reported. Only the natural isomer was found to activate the PPAR $\gamma$ receptor, and this phenomenon could be explained based on molecular docking studies. In addition, the pharmacological profiles of the isomers were determined using the $\mathrm{GABA}_{\mathrm{A}}$ (gamma-aminobutyric acid A) ion channel receptor as a representative target for allosteric modulation related to diverse CNS activities. These compounds were found to be weak allosteric modulators of the $\alpha 1 \beta 3$ and $\alpha 1 \beta 2 \gamma 2$ receptor subtypes.

$\mathrm{N}$ otoincisol A (1) is a natural product recently isolated from the roots and rhizomes of Notopterygium incisum Ting ex H.T. Chang (Umbelliferae). ${ }^{1}$ The dried roots of $N$. incisum, known as "Qiang Huo", have been used in traditional Chinese medicine as a treatment against the common cold and inflammatory diseases such as rheumatoid arthritis, as well as a diaphoretic, antifebrile agent, and analgesic. ${ }^{2}$ Compound 1 belongs to the class of polyeneynes, featuring adjacent triplebond systems in immediate or close proximity to olefinic systems (or functional groups derived thereof) as the main structural motif within their molecular architecture. One of the most studied polyeneyne compounds is falcarindiol (2) (Figure 1), which is abundant in several vegetables such as celery or parsley and responsible for the bitterness of carrots. Some polyeneynes are highly toxic, as for instance cicutoxin (3) or oenanthotoxin (4) (Figure 1). However, several studies have demonstrated possible positive biological effects of certain polyeneynes, as for instance some of the compounds possess antifungal, anti-inflammatory, or cytotoxic properties. ${ }^{3}$ It was, therefore, hypothesized that polyeneynes can be classified as toxicants, compounds being toxic at higher doses, but showing beneficial effects at lower concentrations. ${ }^{3-7}$

Within a multidisciplinary research program ${ }^{8}$ aimed at the identification of novel natural products displaying antiinflammatory activity, ${ }^{9,10}$ we became interested in the synthesis of polyeneynes such as $\mathbf{1}$ to confirm the absolute configuration of this natural product as well as to investigate the prospects of further developing this structural lead. Notoincisol A (1) has been shown to possess PPAR $\gamma$-agonistic activity, with an $\mathrm{EC}_{50}$ of $2.3 \mu \mathrm{M}$ and a maximum fold activation of $E_{\max }=2.8$. PPAR $\gamma$ is a nuclear receptor that acts as a transcription factor regulating target genes of lipid metabolism and inflammation. Upon ligand binding and activation, PPAR $\gamma$ forms a heterodimer with RXR (retinoid X receptor) and subsequently

Received: June 1, 2018

Published: October 26, 2018 


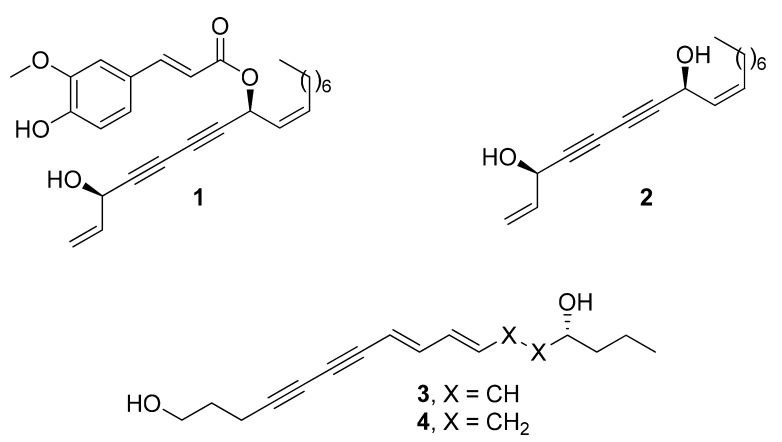

Figure 1. Notoincisol A (1) and related natural products (2-4) from the polyeneyne class.

recruits coactivators, necessary for its transactivation activity. $\operatorname{PPAR} \gamma$ was recognized as a potential anti-inflammatory target in 1998, when it was shown that activation of the receptor leads to the inhibition of NF- $\kappa \mathrm{B}$ (nuclear factor "kappa-lightchain-enhancer" of activated B cells), a transcription factor regulating the expression of pro-inflammatory target genes. $^{11-13}$

It was considered reasonable to believe that the biosynthesis of 1 proceeds via falcarindiol (2), and therefore its absolute configuration could be deduced; however, only the relative stereochemistry of the natural product was confirmed by means of $2 \mathrm{D}$ NMR techniques. ${ }^{1}$ This prompted the preparation of all possible stereoisomers and the comparison of the physical data of the synthetic and isolated compounds to be performed. Moreover, this approach also enabled a biological assessment of the synthetic isomers.

It has been shown previously that the neurotoxicity of cicutoxin (3) and oenanthotoxin (4) originates from an antagonistic effect of these compounds on $\mathrm{GABA}_{\mathrm{A}}$ receptors. ${ }^{14}$ In contrast, several other polyeneynes (e.g., falcarindiol and falcarinol) have been described as positive modulators of these ion channels. ${ }^{15,16}$ This interesting diversity in the biological behavior of the members of the same compound class prompted also an investigation of the modulatory action of notoincisol A (1) and its synthesized isomers on two $\mathrm{GABA}_{\mathrm{A}}$ receptor subtypes, in line with previous studies of naturalproduct-derived molecules on this target family. ${ }^{17-21}$ Moreover, the lipophilic nature of the polyeneynes raised the question as to whether the mode of action of these compounds can be the same as that of other fatty-acid-derived lipophilic molecules, such as 2-AG (2-arachidonglycerol) or NA-glycine ( $\mathrm{N}$-arachidonylglycine). These endogenous ligands of the cannabinoid system are known to enhance the GABA-induced current of receptors containing a $\beta 2$ subunit. ${ }^{22}$

The $\mathrm{GABA}_{\mathrm{A}}$ receptor is a ligand-gated chloride ion channel. Its endogenous ligand, $\gamma$-aminobutyric acid (GABA), is the main inhibitory neurotransmitter in the CNS. Upon binding of GABA, chloride and bicarbonate ions can pass the neuronal cell membrane. Consequently, hyperpolarization takes place, thus reducing the likelihood that an action potential will occur. Structurally, the $\mathrm{GABA}_{\mathrm{A}}$ receptor is a member of the Cys-loop pentameric LGIC superfamily. In mammals, 19 different subunits are known to exist. The subunit composition of the $\mathrm{GABA}_{\mathrm{A}}$ receptor plays a crucial role in the pharmacological effect of the receptor. It has been demonstrated that different $\mathrm{GABA}_{\mathrm{A}}$ subtypes are responsible for various pharmacological actions. $^{23,24}$

A retrosynthetic analysis of notoincisol A (1) suggested that proper functional decoration (employing ferulic acid derivatives) of a falcarindiol analogue as a precursor could be used to exploit previous synthetic approaches to such structures. ${ }^{25-29}$ The key connection of two alkyne synthons was planned via copper-catalyzed Cadiot-Chodkiewicz coupling ${ }^{30}$ of two alkyne units. Selectivity of the esterification of the alcohol at position C-8 was ensured by protection of the alcohol moiety of the "short" alkyne prior to the Cadiot-Chokiewitz reaction (Scheme 1).

Aiming at the preparation of all four stereoisomers, lipasemediated kinetic resolution was considered as a beneficial method for the stereochemical discrimination of the racemic synthons. Both $S$ - and $R$-enantiomers can be obtained from corresponding racemic synthons in a single operation. All possible combinations of the short-chain with the long-chain synthon led to four stereoisomers of the falcarindiol (2) backbone (Scheme 2).

Synthesis of the short Cadiot-Chodkiewicz coupling partners began with the preparation of alcohol rac-6 by addition of trimethylsilyl (TMS)-acetylene to acrolein in $89 \%$ yield. Subjecting rac-6 to Amano lipase PS $^{26}$ and chromatographic separation led to the isolation of the enantiomerically enriched ester $R-7$ in $48 \%$ yield and alcohol $S-6$ in 33\% yield. The optical purity of the synthons was controlled by chiral HPLC. A method for resolving the racemic acetate $\mathrm{rac}^{-7}$ was established, and the optical purity control of acetate $R-7$ could be carried out directly. Despite an extended effort to identify conditions for resolving the racemic alcohol rac-6 (for the control of the optical purity of alcohol S-6), this was not successful. Therefore, alcohol S-6 initially was chemically acetylated and subsequently subjected to chiral HPLC analysis

\section{Scheme 1. Retrosynthetic Analysis of Notoincisol A (1)}
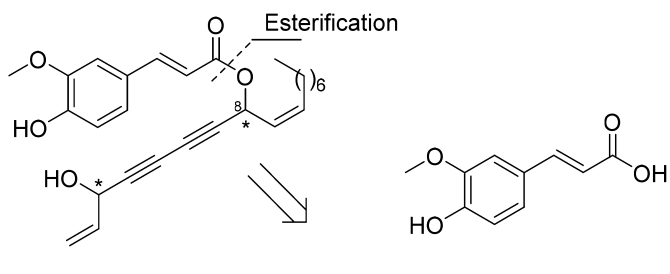

Notoincisol A (1)

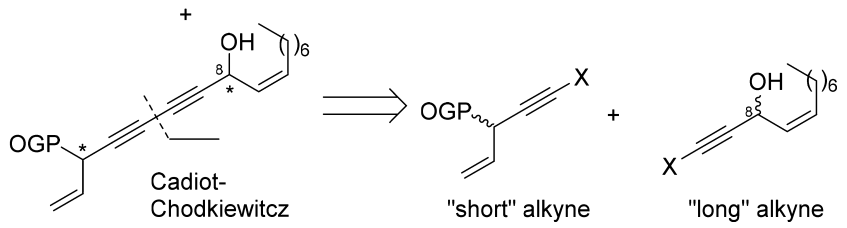


Scheme 2. Strategy for Facile Access to All Necessary Enantiomerically Enriched Synthons

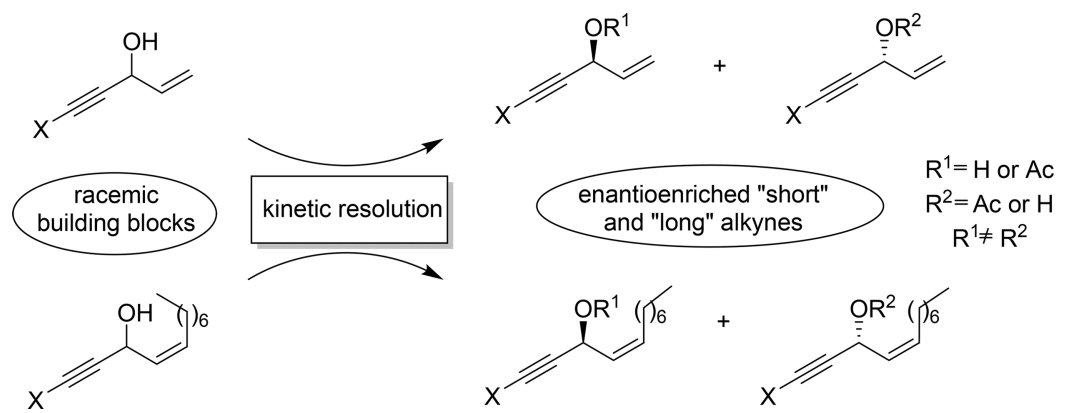

Scheme 3. Kinetic Resolution of Alcohol rac-6 and the Method for the Control of Optical Purity ${ }^{a}$

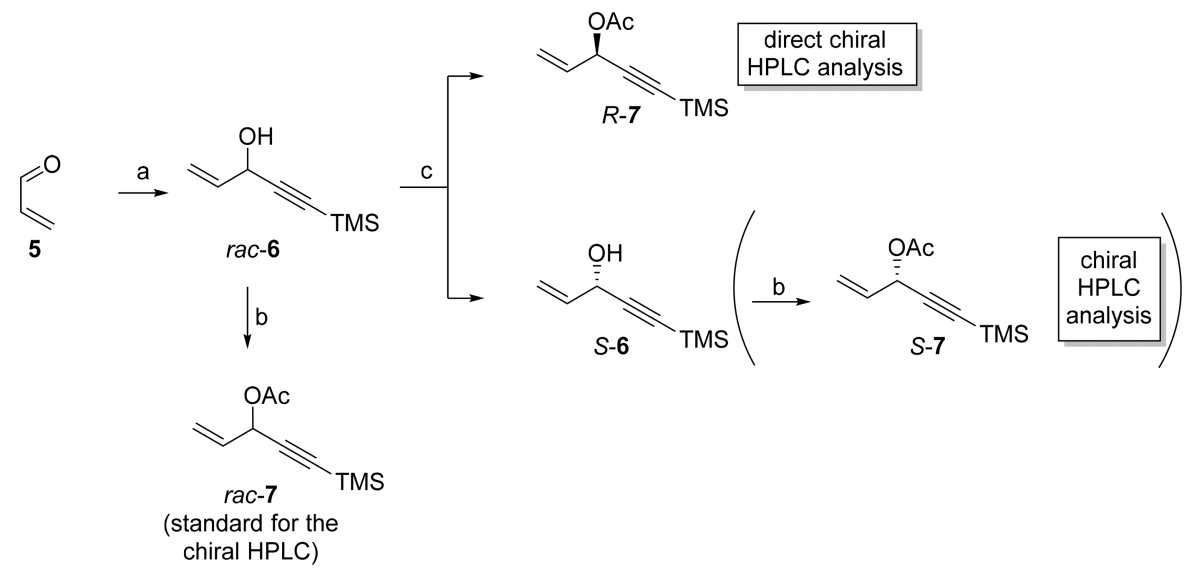

${ }^{a}$ Reaction conditions: (a) $n$-BuLi, TMS-acetylene, THF, $0{ }^{\circ} \mathrm{C}$ to rt, 4 h, $89 \%$; (b) $\mathrm{Ac}_{2} \mathrm{O}, \mathrm{DMAP}_{3} \mathrm{Et}_{3} \mathrm{~N}, \mathrm{CH}_{2} \mathrm{Cl}_{2}$, rt, 15 min; (c) Amano lipase PS, MTBE, vinyl acetate, rt, $4 \mathrm{~h}, 48 \%$ for $R-7,33 \%$ for S-6.

as the corresponding acetate $S$-7. It was determined that acetate R-7 and alcohol S-6 were formed with ee's of $>99 \%$ in both cases. The absolute configuration of the building blocks was determined by comparison of optical rotations of the synthesized compounds with the known values from the literature (see Experimental Section). It was confirmed that the $R$-enantiomer of $\mathbf{6}$ undergoes lipase-mediated acetylation, whereas the $S$-enantiomer remained intact (Scheme 3 ).

Subjecting ester $R-7$ to basic hydrolysis led to the cleavage of both the TMS and acyl groups and furnished alcohol R-8 in $82 \%$ yield. When followed by tert-butyl(dimethyl)silyl (TBS) protection, this yielded primary alkyne $R-10$ in $91 \%$ yield. Alcohol S-6 was further protected with a TBS group, affording compound $S-9$ in $93 \%$ yield, and subsequent hydrolysis of the TMS group provided primary alkyne $S-10$ in a $78 \%$ yield (Scheme 4).

The synthesis of rac-13 started on the reduction of commercially available dec-2-ynol (11). In contrast to previous reports in the literature, ${ }^{27,29}$ hydrogenation toward $Z$-allylic alcohol employing Lindlar's catalyst failed in our hands due to over-reduction and poor reproducibility (see Supporting Information). This was solved by changing to a nickel P-2 catalyst, ${ }^{31}$ providing exclusively the $Z$ alkene in a quantitative fashion without further purification. Subsequent oxidation of the allylic alcohol to the corresponding enal 12 required a careful choice of reaction conditions in order to avoid isomerization of the double bond (see Supporting Information). Due to the limited stability of the intermediate, the crude material obtained was employed immediately in the
Scheme 4. Synthesis of Enantioenriched Alkynes R-10 and $S-10^{a}$
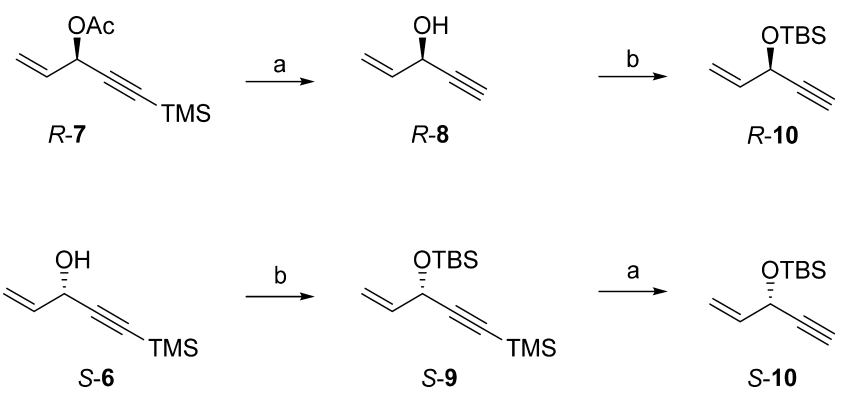

${ }^{a}$ Reaction conditions: (a) $\mathrm{K}_{2} \mathrm{CO}_{3}, \mathrm{MeOH}, \mathrm{rt}, 2 \mathrm{~h}, 82 \%$ yield for $\mathrm{R}-\mathbf{8}$, $78 \%$ yield for $\mathrm{S}-10$; (b) TBSCl, imidazole, $\mathrm{CH}_{2} \mathrm{Cl}_{2}, \mathrm{rt}, 91 \%$ yield for $R-10,93 \%$ yield for $S-9$.

subsequent addition of the TMS-acetylene. Racemic alcohol rac-13 was finally isolated in $60 \%$ yield over three steps.

Rac-13 has not been reported as a substrate for a lipasemediated kinetic resolution to date. Amano lipase PS turned out to accept rac-13, but the reaction proceeded significantly slower than in the case of rac-6. Nevertheless, after $36 \mathrm{~h}$ ester $R-14$ was isolated in $48 \%$ yield and the remaining alcohol $S-15$ in $45 \%$ yield (Scheme 5 ).

Analysis of the optical purity was carried out in a similar manner to that for the resolution of the alcohol rac-6. Acetate $R-14$ was analyzed directly, whereas alcohol $S$-15 was acetylated prior to the analysis. Similar to the previous case, kinetic resolution proceeded with a high level of selectivity, and 
Scheme 5. Synthesis of Enantioenriched Alkynes $R-14$ and $S-15^{a}$

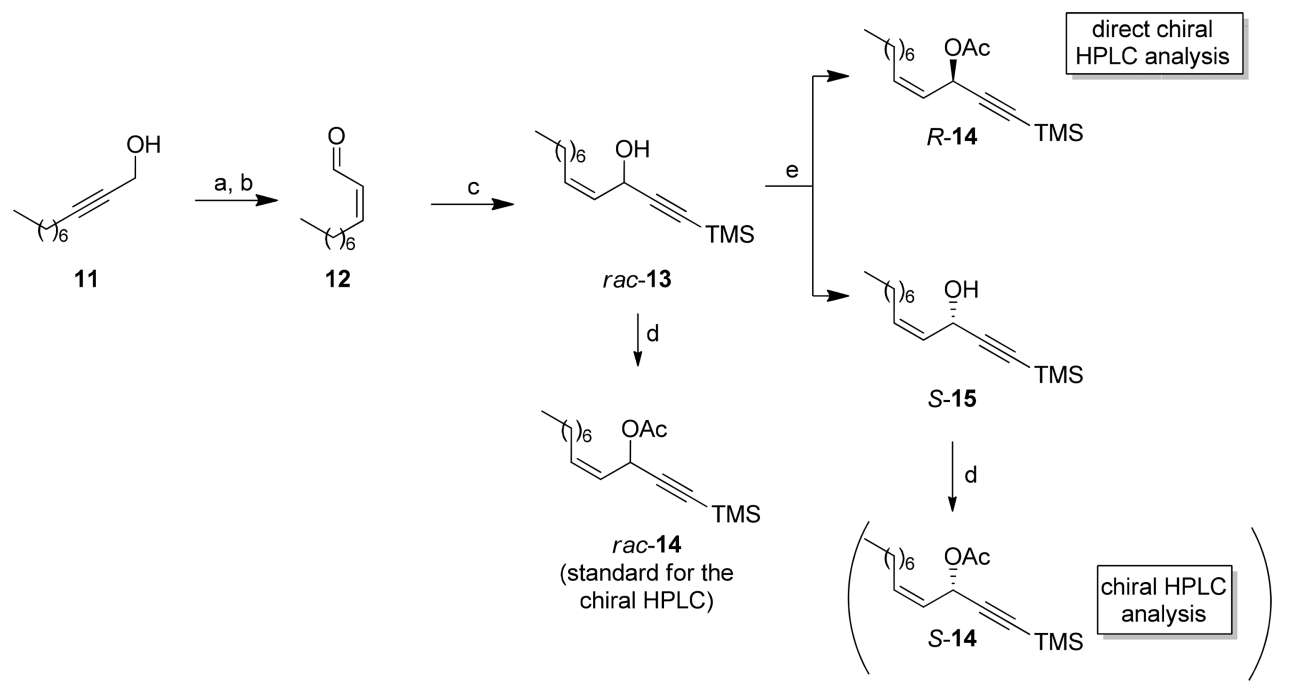

${ }^{a}$ Reaction conditions: (a) Ni(OAc) $)_{2} \cdot 4 \mathrm{H}_{2} \mathrm{O}, \mathrm{NaBH}_{4},\left(\mathrm{CH}_{2} \mathrm{NH}_{2}\right)_{2}, \mathrm{MeOH}, \mathrm{rt}, 3 \mathrm{~h}$; (b) IBX, DMSO $/ \mathrm{CH}_{2} \mathrm{Cl}_{2}, \mathrm{rt}, 2$ h; (c) TMS acetylene, $n$-BuLi, THF, $-78{ }^{\circ} \mathrm{C}$ to $\mathrm{rt}, 2.5 \mathrm{~h}, 60 \%$ over three steps; (d) amano lipase PS, MTBE, vinyl acetate, rt, $36 \mathrm{~h}, 48 \%$, ee $>99 \%$ for $R-14,45 \%$, ee $>99 \%$ for $S$ 15.

both synthons were isolated with ee's of $>99 \%$ (Table 1). Determination of the absolute configuration was again carried

Table 1. Optimization of the Reaction Time for the Kinetic Resolution of rac-14

$\begin{array}{ccccc}\begin{array}{c}\text { time } \\ (\mathrm{h})\end{array} & \begin{array}{c}\text { yield alcohol } \\ (\%)\end{array} & \begin{array}{c}\text { ee alcohol } \\ (\%)\end{array} & \begin{array}{c}\text { yield acetate } \\ (\%)\end{array} & \begin{array}{c}\text { ee acetate } \\ (\%)\end{array} \\ 12 & 48 & >99 & 30 & 50 \\ 24 & 50 & >99 & 42 & 88 \\ 36 & 45 & >99 & 45 & >99\end{array}$

out by means of comparison of optical rotation values. It was determined that the $R$-enantiomer of $\mathbf{1 3}$ undergoes acetylation, while the $S$-enantiomer remains intact. Additional control experiments for the absolute chemistry determination were carried out (see Supporting Information).

Both compounds R-14 and S-15 were subjected to basic hydrolysis, yielding the enantiomerically enriched primary alkynes $R-16$ and $S-16$ in $85 \%$ and $81 \%$ yields, respectively. Bromination of the triple bonds furnished the corresponding bromoalkynes $R-\mathbf{1 7}$ and $S-\mathbf{1 7}$ in $81 \%$ and $77 \%$ yields, respectively (Scheme 6).

Scheme 6. Synthesis of Enantioenriched Alkyne Bromides $R-17$ and $S-17^{a}$

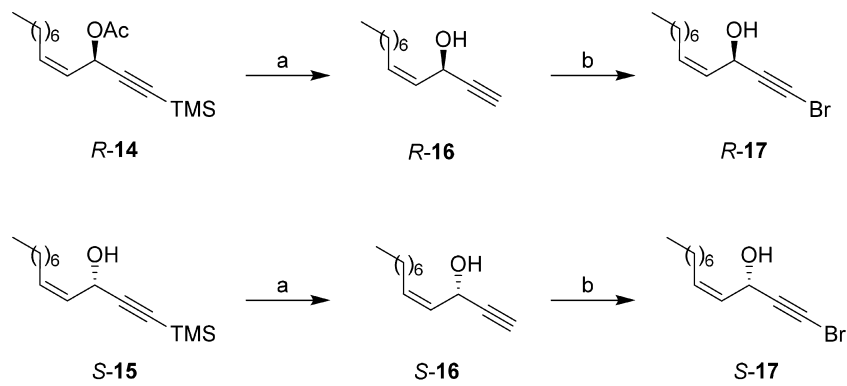

${ }^{a}$ (a) $\mathrm{K}_{2} \mathrm{CO}_{3}, \mathrm{MeOH}, \mathrm{rt}, 2 \mathrm{~h}, 85 \%$ for $\mathrm{R}-\mathbf{1 6}$, 81\% for S-16; (b) $\mathrm{AgNO}_{3}$, NBS, acetone, $2 \mathrm{~h}$, rt, $81 \%$ for $R-17,77 \%$ for $S-17$.
In the next step, all possible combinations of alkyne bromides and the primary alkyne were coupled within the Cadiot-Chodkiewicz reaction, furnishing four stereoisomers (20) in an average yield of $65 \%$. Subsequent esterification with TBS-protected ferulic acid yielded protected stereoisomers of notoincisol A (21) (Scheme 7).

Finally, global deprotection using HF.pyridine gave notoincisol A (1) as well as all the stereoisomers in yields between $75 \%$ and $83 \%$ (Scheme 5 and Table 1).

Comparison of the optical rotation of the natural product $\left([\alpha]^{20}{ }_{D}+85.5\right)^{1}$ and synthetic compounds revealed that the absolute configuration of the natural product is $3 R, 8 S$, as the value of the synthetic product matched $[\alpha]^{20}{ }_{\mathrm{D}}+87.7$. The value measured for the enantiomer, $3 S, 8 R$-notoincisol $\mathrm{A}$, was $[\alpha]^{20}-85.9$, and those for the diastereomers $3 S, 8 S$ notoincisol $\mathrm{A}$ and $3 R, 8 R$-notoincisol $\mathrm{A}$ were $[\alpha]^{20}{ }_{\mathrm{D}}+134.1$ and -139.8 , respectively (Scheme 5).

All synthesized compounds were investigated for their agonistic activity on the PPAR $\gamma$ receptor in a luciferase-based transactivation model in HEK293 cells, as described before. ${ }^{32}$ Interestingly, all of the unnatural isomers were found to be inactive up to a concentration of $3 \mu \mathrm{M}$. Higher concentrations were not tested since the unnatural isomers appeared to be cytotoxic at a concentration of $10 \mu \mathrm{M}$, which was shown by a resazurin conversion assay (Supporting Information). The natural isomer $3 R, 8 S-1$ activated the PPAR $\gamma$ receptor with an $\mathrm{EC}_{50}$ of $1.19 \mu \mathrm{M}$ and a maximal fold activation of $E_{\max }=3.38$, which is in reasonable agreement with data obtained from the natural product isolate $\left(\mathrm{EC}_{50} 2.3 \mu \mathrm{M}, E_{\max } 2.8\right) .{ }^{1}$ As a positive control, the PPAR $\gamma$ agonist pioglitazone was used.

Since only compound 3R,8S-1 displayed PPAR $\gamma$-activating properties, a molecular docking study was conducted to rationalize this observation. All four notoincosol isomers were docked into the X-ray crystal structure of human PPAR $\gamma$ initially complexed with magnolol (PDB entry $3 r 5 n)^{33}$ and fitted into the binding site without producing steric clashes. However, the inactive isomers were poorly anchored in the binding site with only one hydrogen bond or not filling all three arms of the pocket. Compound $3 R, 8 S-1$ was the only 
Scheme 7. Key Cadiot-Chodkiewitz Coupling of Enantioenriched Building Blocks and Esterification with TBS-Ferulic Acid ${ }^{a}$<smiles>COc1cc(/C=C/C(=O)O)ccc1O</smiles>

18<smiles></smiles><smiles></smiles><smiles>CCCCOc1c(/C=C/C(=O)O)cccc1OC</smiles>

19

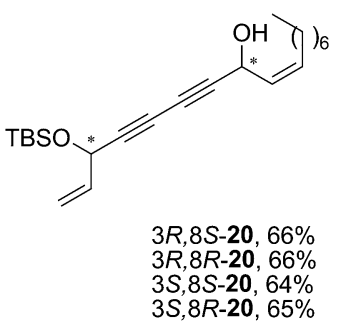<smiles>CCC1CC1</smiles><smiles>C=CC(C#CC#CC(/C=C\C)OC(=O)/C=C/c1ccc(OC(C)(C)C)c(OC)c1)=C(C)C</smiles>

$3 R, 8 S-21,81 \%$ $3 R, 8 R-21,78 \%$

$3 S, 8 R-21,78 \%$

${ }^{a}$ Reaction conditions: (a) TBSCl, imidazole, DMF, rt, 67\%; (b) (i) TBSCl, imidazole, $\mathrm{CH}_{2} \mathrm{Cl}_{2}$, rt, (ii) THF/ $\mathrm{MeOH}, \mathrm{H}_{2} \mathrm{O}, \mathrm{K}_{2} \mathrm{CO}_{3}, 89 \%$, yield after two steps; (c) $\mathrm{NH}_{2} \mathrm{OH} \cdot \mathrm{HCl}, \mathrm{EtNH}_{2}, \mathrm{CuCl}, \mathrm{H}_{2} \mathrm{O} / \mathrm{MeOH}, 0{ }^{\circ} \mathrm{C}$ to rt, $2 \mathrm{~h}$; (d) TBS-ferulic acid, EDCI, DMAP.

Scheme 8. Deprotection of TBS Groups ${ }^{a}$

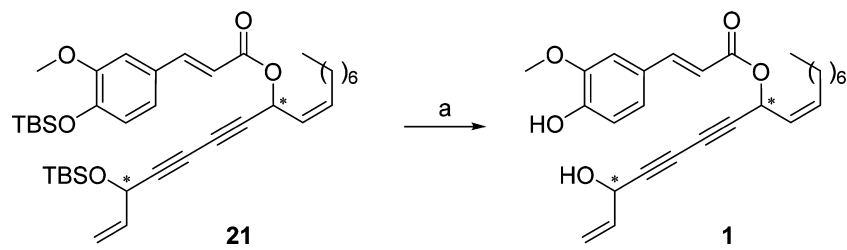

${ }^{a}$ Reaction conditions: (a) HF.pyridine, THF, $0{ }^{\circ} \mathrm{C}$ to rt.

Table 2. Yields of the Deprotection Products and Optical Rotations of the Synthetic Compounds

$\begin{array}{cccc}\text { starting material } & \text { product } & \text { yield }(\%) & \text { optical rotation }(c 0.09, \mathrm{MeOH}) \\ 3 R, 8 S-21 & 3 R, 8 S-\mathbf{1} & 83 & +87.7 \\ 3 R, 8 R-21 & 3 R, 8 R-1 & 78 & -139.8 \\ 3 S, 8 S-21 & 3 S, 8 S-1 & 76 & +143.1 \\ 3 S, 8 R-21 & 3 S, 8 R-1 & 75 & -85.9\end{array}$

Table 3. Effects of Compounds 3R,8S-1, 3R,8R-1, 3S,8S-1, and $3 S, 8 R-1$ on Human PPAR $\gamma$-Mediated Luciferase Reporter Gene Transactivation

$\begin{array}{lcc}\text { compound } & \mathrm{EC}_{50}(\mu \mathrm{M}) & E_{\max } \\ 3 R, 8 S-\mathbf{1} & 1.2 & 3.38 \pm 0.26 \\ 3 R, 8 R-1 & \text { n.d. } & \\ 3 S, 8 S-1 & \text { n.d } & \\ 3 S, 8 R-1 & \text { n.d } & \\ \text { pioglitazone } & 0.10 & 9.15 \pm 0.45\end{array}$

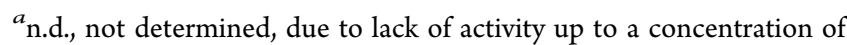
$3 \mu \mathrm{M}$.

compound that was tightly anchored by a bifurcated hydrogen bond with Ser289 and Tyr327, filling all three binding site arms, respectively (Figure 2).

We next evaluated the synthetic compounds on two $\mathrm{GABA}_{\mathrm{A}}$ receptor subtypes, in order to assess whether they displayed similar activities to other members of polyeneyne class of natural compounds. All four notoincisol A isomers were investigated using the two electrode voltage (TEV) clamp method in Xenopus laevis oocytes, using a protocol described

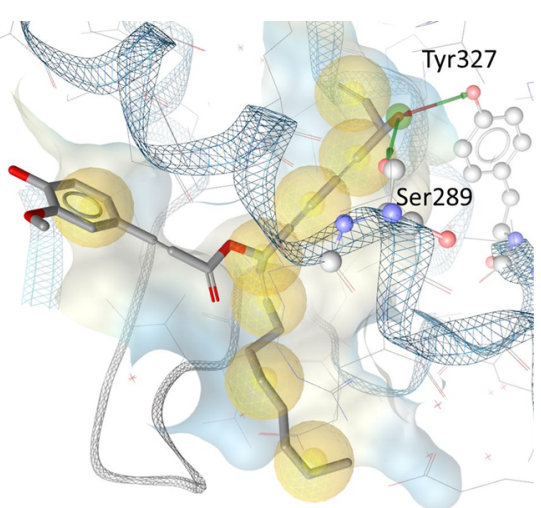

Figure 2. Predicted binding pose of compound $3 R, 8 S-1$ in the ligand binding site of PPAR $\gamma$. The molecule is anchored via a bifurcated hydrogen bond with Tyr327 and Ser289 and forms numerous hydrophobic contacts with the adjacent amino acids (yellow). Red and green arrows represent hydrogen bond acceptors and donors, respectively. The binding site surface is colored by aggregated hydrophobicity (gray) and hydrophilicity (blue).

previously. ${ }^{18}$ First, we tested the most abundant CNS GABA receptor-subtype $\alpha 1 \beta 2 \gamma 2$. Moderate enhancement of GABAelicited currents at GABA EC3-5 was observed for all compounds starting at $1 \mu \mathrm{M}$, with effects reaching $\sim 4$-fold potentiation of the GABA current at $10 \mu \mathrm{M}$ (Supporting Information). This is consistent with an allosteric modulatory action of moderate potency of the compounds. In addition, all four notoincisol A isomers also triggered small GABAindependent currents if applied to the oocyte in the absence of GABA (Supporting Information). These observations inspired an investigation as to whether these polyene compounds display similar subtype selectivity to the endocannabinoid compounds $2-\mathrm{AG}$ and NA-glycine, ${ }^{22,34,35}$ and so they were tested also in $\alpha 1 \beta 3$ receptors with the same protocol. Interestingly, in these receptors, the currents were also potentiated by all four notoincisol $\mathrm{A}$ isomers, but the potentiated currents did not reach maximum strength during standard recording times, ${ }^{18}$ and not even at longer (120 s) recording times, while reaching saturation after $30 \mathrm{~s}$ for the $\alpha 1 \beta 2 \gamma 2$ receptor. A similarly slow current rise has been 
observed for NA-glycine in the $\alpha 1 \beta 2 \gamma 2$ subtype. ${ }^{19}$ The GABAindependent currents in this subtype were observed to be smaller compared to those seen in the $\alpha 1 \beta 2 \gamma 2$ receptor. Since $\beta 3$-containing receptors were also potentiated, the mechanism by which the notoincisol $A$ isomers potentiate $G_{A B A}$ receptors is different from either 2-AG or NA-glycine, which both show $\beta 2$-type selectivity. ${ }^{22,34,35}$ Since effects on GABA $_{A}$ receptors were of low potency, they are unlikely to be of physiological relevance and were not studied in more detail.

\section{EXPERIMENTAL SECTION}

General Experimental Procedures. Unless noted otherwise, all reagents were purchased from commercial suppliers and used without further purification. Melting points were recorded on a Büchi B-545 melting point apparatus. HRMS were measured at a Shimadzu HPLCIT-TOF mass spectrometer with either the APCI or ESI ionization method. Specific rotation was measured on an Anton Paar MCP500 polarimeter at the specified conditions. ${ }^{1} \mathrm{H}$ and ${ }^{13} \mathrm{C}$ NMR spectra were recorded with a Bruker AC $200(200 \mathrm{MHz})$ or a Bruker Avance $400(400 \mathrm{MHz})$ spectrometer using $\mathrm{CDCl}_{3}$ as solvent unless otherwise noted. GC/MS spectra were measured on a ThermoFinnigan system: GC: Focus GC with a BGB5 column $\left(l=30 \mathrm{~m}, d_{\mathrm{i}}=0.25\right.$ $\mathrm{mm}, 0.25 \mu \mathrm{m}$ film), MS: DSQ II with quadrupol (EI) Instrument I or Thermo Ion Trap ITQ 100: Trace Ultra with PTV with a BGB-5 column, MS: ion trap detector (EI and CI) Instrument II. For thinlayer chromatography (TLC), aluminum-backed silica gel 60 F254 (Merck) was used. Medium-pressure liquid chromatography was performed on a Büchi Sepacore Flash System. Pump-System: 2x Büchi pump module C-605, Büchi pump manager C-615; detector: Büchi UV photometer C-635; fraction collector: Büchi fraction collector C-660 or standard manual glass columns using silica gel from Merck $(40-63 \mu \mathrm{m})$. Optical purity was determined by a Thermo Scientific/HPLC Ultimate 3000 HPLC with DAD and IR detectors, using a Chiralpack I.A column with a 99.9:0.1 heptane/2-propanol solvent mixture and $0.8 \mathrm{~mL} / \mathrm{min}$ flow rate. Microwave reactions were carried out in a BIOTAGE Initiator 60. Spectroscopic characterization of all synthesized compounds can be found in the Supporting Information.

5-(Trimethylsilyl)pent-1-en-4-yn-3-ol (rac-6). An oven-dried $500 \mathrm{~mL}$ three-necked round-bottom flask equipped with a septum, gas inlet, and low-temperature thermometer was evacuated, and the atmosphere was exchanged for argon. Trimethylsilylacetylene $(5 \mathrm{~mL}$, $3.45 \mathrm{~g}, 35 \mathrm{mmol})$ and dry tetrahydrofuran (THF) $(140 \mathrm{~mL})$ were added via a septum. The reaction mixture was cooled to $-78{ }^{\circ} \mathrm{C}$, and $n$-BuLi $(21.9 \mathrm{~mL}, 1.6 \mathrm{M}, 35 \mathrm{mmol})$ was added slowly. The reaction solution was stirred for $30 \mathrm{~min}$ at $-78{ }^{\circ} \mathrm{C}$, and then acrolein was added in one portion. The mixture turned light blue. The cooling bath was removed, and the reaction solution was allowed to reach room temperature and was stirred for $2 \mathrm{~h}$. When the reaction was completed (TLC), water was added $(150 \mathrm{~mL})$ and the mixture was extracted with ethyl acetate $(3 \times 150 \mathrm{~mL})$. The combined organic layers were washed with brine and dried over sodium sulfate. Solvents were evaporated, and the residue was submitted to column chromatography using silica and petroleum ether/EtOAc (90:10), yielding 4.81 $\mathrm{g}(89 \%)$ of $r a c-6$ as a colorless liquid. Spectroscopic data agreed with literature values. ${ }^{26}$

Kinetic Resolution of Racemic 5-(Trimethylsilyl)pent-1-en4-yn-3-ol (rac-6). A $250 \mathrm{~mL}$ round-bottom flask was charged with rac-6 (4.6 g, $29.8 \mathrm{~mol})$, lipase PS (915 g, $20 \mathrm{w} \%)$, vinyl acetate (3.16 $\mathrm{mL}, 2.95 \mathrm{~g}, 34.3 \mathrm{mmol}$ ), and methyl tert-butyl ether (MTBE) (107 $\mathrm{mL})$. The flask was sealed with a septum, and the reaction mixture was stirred for $3 \mathrm{~h}$. After the reaction was completed, the reaction mixture was filtered through a pad of Celite and solvents were evaporated in vacuo. Column chromatography with silica gel and petroleum ether/EtOAc (99:1) provided the desired products $R-7$ and $S-6$.

(R)-Pent-1-en-4-yn-3-ol ( $R$-8). (R)-5-(Trimethylsilyl)pent-1-en4-yn-3-yl acetate $(R-7)(1.62 \mathrm{~g}, 8.2 \mathrm{mmol})$ was charged into a $100 \mathrm{~mL}$ round-bottom flask. Then, $30 \mathrm{~mL}$ of methanol was added, followed by the addition of potassium carbonate $(2.8 \mathrm{~g}, 20.5 \mathrm{mmol})$. The reaction mixture was stirred for $2 \mathrm{~h}$ at room temperature. After the reaction was completed, water was added $(30 \mathrm{~mL})$ and the mixture was extracted repeatedly with diethyl ether, until no more product remained in the water phase, as controlled by TLC. The combined organic layers were washed with brine, dried over sodium sulfate, and filtered. Solvents were evaporated and dried at $30{ }^{\circ} \mathrm{C}$ at a minimum of 100 mbar. The mixture was redissolved in $\mathrm{CH}_{2} \mathrm{Cl}_{2}$ and filtered through a pad of silica, and the solvent was evaporated as described before, yielding $82 \%$ of alcohol $R-8$ as a colorless liquid. The spectroscopic data obtained agreed with literature values. ${ }^{36}$

$(R)$-tert-Butyldimethyl(pent-1-en-4-yn-3-yloxy)silane ( $R$ - 10$)$. (R)-Pent-1-en-4-yn-3-ol (R-8) (411 mg, $5 \mathrm{mmol})$ and imidazole $(749$ $\mathrm{mg}, 11 \mathrm{mmol}$ ) were dissolved in $35 \mathrm{~mL}$ of dry $\mathrm{CH}_{2} \mathrm{Cl}_{2}$. The mixture was cooled to $0{ }^{\circ} \mathrm{C}$, and $\mathrm{TBSCl}(829 \mathrm{mg}, 5.5 \mathrm{mmol})$ was added. The ice bath was removed, and the resulting mixture was stirred at room temperature for $2 \mathrm{~h}$. After this time, the reaction was quenched with water $(30 \mathrm{~mL})$, the layers were separated, and the aqueous phase was extracted with $\mathrm{CH}_{2} \mathrm{Cl}_{2}(2 \times 30 \mathrm{~mL})$. The combined organic layers were washed with brine, dried over sodium sulfate, and filtered. The mixture was concentrated at reduced pressure. The resulting residue was passed through a pad of silica, using $\mathrm{CH}_{2} \mathrm{Cl}_{2}$ as eluent. The solvent was removed under reduced pressure, affording $R-10$ in $91 \%$ yield as a colorless liquid. The spectroscopic data obtained agreed with literature values. ${ }^{3}$

(S)-tert-Butyldimethyl((5-(trimethylsilyl)pent-1-en-4-yn-3yl)oxy)silane (S-9). (S)-5-(Trimethylsilyl)pent-1-en-4-yn-3-ol (S-6) $(1.7 \mathrm{~g}, 11 \mathrm{mmol})$ and imidazole $(1.65 \mathrm{~g}, 11 \mathrm{mmol})$ were dissolved in $90 \mathrm{~mL}$ of dry $\mathrm{CH}_{2} \mathrm{Cl}_{2}$. The mixture was cooled to $0{ }^{\circ} \mathrm{C}$, and $\mathrm{TBSCl}$ $(1.83 \mathrm{~g}, 12.4 \mathrm{mmol})$ was added. The ice bath was removed, and the resulting mixture stirred at room temperature for $2 \mathrm{~h}$. After this time, the reaction was quenched with water $(90 \mathrm{~mL})$, the layers were separated, and the aqueous phase was extracted with $\mathrm{CH}_{2} \mathrm{Cl}_{2}(2 \times 90$ $\mathrm{mL}$ ). The combined organic layers were washed with brine, dried over sodium sulfate, and filtered. The mixture was concentrated at reduced pressure. The resulting residue was passed through a pad of silica, using $\mathrm{CH}_{2} \mathrm{Cl}_{2}$ as eluent. The solvent was distilled off under reduced pressure, affording $S-9$ in $93 \%$ yield as a colorless liquid. The spectroscopic data obtained agreed with literature values. ${ }^{23,37}$

(S)-tert-Butyldimethyl(pent-1-en-4-yn-3-yloxy)silane (S-10). (S)-tert-Butyldimethyl((5-(trimethylsilyl)pent-1-en-4-yn-3-yl)oxy)silane $(S-9)(1.88 \mathrm{~g}, 7 \mathrm{mmol})$ was charged into a $100 \mathrm{~mL}$ roundbottom flask. Then, $50 \mathrm{~mL}$ of methanol was added, followed by the addition of potassium carbonate $(1.93 \mathrm{~g}, 14 \mathrm{mmol})$. The reaction mixture was stirred for $2 \mathrm{~h}$ at room temperature. After the reaction was completed, water was added $(30 \mathrm{~mL})$ and the mixture extracted with EtOAc $(3 \times 50 \mathrm{~mL})$. The combined organic layers were washed with brine, dried over sodium sulfate, and filtered. Solvents were evaporated under reduced pressure. The mixture was redissolved in $\mathrm{CH}_{2} \mathrm{Cl}_{2}$, filtered through a pad of silica, and concentrated under reduced pressure, yielding $78 \%$ of alkyne $S-10$ as a colorless liquid. $R_{f}$ 0.63 (petroleum ether/EtOAc, 9:1). The spectroscopic data obtained agreed with literature values. ${ }^{37}$

(Z)-Dec-2-enal (12). In a $250 \mathrm{~mL}$ three-neck round-bottom flask equipped with a septum and gas inlet, $\mathrm{Ni}(\mathrm{OAc})_{2} \cdot 4 \mathrm{H}_{2} \mathrm{O}$ (0.38 equiv, $14.4 \mathrm{mmol}, 2.98 \mathrm{~g}$ ) was dissolved in $47 \mathrm{~mL}$ of methanol, the atmosphere was changed to argon, and the reaction mixture was cooled with an ice bath. $\mathrm{NaBH}_{4}(2.98 \mathrm{~g}, 14.4 \mathrm{mmol})$ was added portionwise. The reaction mixture was allowed to warm to room temperature and was stirred for $15 \mathrm{~min}$. Then, the atmosphere was exchanged for $\mathrm{H}_{2}$. In a separate flask, dec-2-ynol (11) (39 mmol, $6 \mathrm{~g}$ ) was dissolved in $20 \mathrm{~mL}$ of methanol together with ethane-1,2-diamine (0.94 equiv, $35.7 \mathrm{mmol}, 2.38 \mathrm{~mL}$ ), and the reaction mixture was transferred via syringe into the mixture of the catalyst. The reaction was stirred at room temperature for $3 \mathrm{~h}$ until full consumption of starting material was observed by TLC. The reaction mixture was filtered through a pad of Celite under reduced pressure, and solvents were evaporated under reduced pressure, yielding $6.08 \mathrm{~g}$ (quantitative) of (Z)-dec-2-en-1-ol as a yellowish oil. The product was used as such for the next step. Its spectroscopic data agreed with the 
literature. ${ }^{24}$ A $500 \mathrm{~mL}$ three-neck round-bottom flask equipped with a septum and inert gas inlet was charged with $(Z)$-dec-2-enol $(5.7 \mathrm{~g}$, $36.4 \mathrm{mmol})$, dry DMSO $(16.6 \mathrm{~mL})$, dry $\mathrm{CH}_{2} \mathrm{Cl}_{2}(78 \mathrm{~mL})$, and 2iodoxybenzoic acid (IBX) (1.5 equiv, $15.3 \mathrm{~g}, 54.7 \mathrm{mmol}$ ). The reaction mixture was stirred for $2 \mathrm{~h}$ at room temperature, and then 0.3 $\mathrm{mL}$ of DMSO was added every $10 \mathrm{~min}$ for $1 \mathrm{~h}$. After the reaction was complete, the mixture was cooled to $0{ }^{\circ} \mathrm{C}$; ice-precooled $\mathrm{NaHCO}_{3}$ was added $(80 \mathrm{~mL})$ and the resulting mixture was stirred for $15 \mathrm{~min}$. All the workup operations were carried out with precooled glassware and ice-bath-precooled chemicals. Solids were removed by filtration via a sintered-glass funnel under reduced pressure. The mixture was extracted with diethyl ether $(100 \mathrm{~mL})$ and washed successively with $\mathrm{NaHCO}_{3}(100 \mathrm{~mL})$ and brine $(100 \mathrm{~mL})$. The organic layer was dried over $\mathrm{Na}_{2} \mathrm{SO}_{4}$ and filtered, and volatiles were evaporated under reduced pressure at room temperature, yielding enal 12 as a yellow oil. The crude material was used immediately for the next step.

(Z)-1-(Trimethylsilyl)dodec-4-en-1-yn-3-ol (rac-13). TMSacetylene $(7.8 \mathrm{~mL}, 55.4 \mathrm{mmol})$ was charged into a predried 250 $\mathrm{mL}$ three-necked round-bottom flask, equipped with a low-temperature thermometer, inert gas inlet, and septum. The atmosphere was exchanged for argon, and dry THF $(34 \mathrm{~mL})$ was added. The reaction mixture was cooled to $-78{ }^{\circ} \mathrm{C}, n-\mathrm{BuLi}$ was added $(1.6 \mathrm{M}, 34.6 \mathrm{~mL}$, $55.4 \mathrm{mmol}$ ), and the reaction mixture was stirred for $30 \mathrm{~min}$ at -78 ${ }^{\circ} \mathrm{C}$. In a separate flask, crude $(Z)$-dec-2-ynal (12) obtained in the previous step was dissolved in dry THF $(48 \mathrm{~mL})$ under an inert atmosphere and transferred subsequently into the reaction mixture via a syringe. The mixture was allowed to warm to room temperature and was stirred for $3 \mathrm{~h}$. After the reaction was finished, water $(100 \mathrm{~mL})$ was added, and the mixture was extracted with ethyl acetate $(3 \times 100$ $\mathrm{mL})$, washed with brine $(100 \mathrm{~mL})$, and filtered through a pad of silica. Compound rac-13 was isolated as a yellowish oil in $60 \%$ yield after two steps. Its spectroscopic data agreed with literature values. ${ }^{24}$

Lipase Kinetic Resolution of Racemic Alcohol (rac-13). A 250 $\mathrm{mL}$ round-bottom flask was charged with racemic (Z)-1(trimethylsilyl)dodec-4-en-1-yn-3-ol ( rac-13) (5.5 g, $21.78 \mathrm{mmol}$ ), lipase PS (1.1 g, $20 \mathrm{w} \%)$, vinyl acetate $(2.3 \mathrm{~mL}, 25.05 \mathrm{mmol})$, and MTBE $(77 \mathrm{~mL})$. The flask was sealed with a septum, and the reaction mixture was stirred for $36 \mathrm{~h}$. After the reaction was finished, the mixture was filtered through a pad of Celite, and solvents were evaporated under vacuum. Column chromatography (silica gel, petroleum ether/EtOAc, 99:1) provided the desired products, $R-14$ and $S-15$.

(S,Z)-Dodec-4-en-1-yn-3-ol (S-16). A $100 \mathrm{~mL}$ round-bottom flask was charged with (S,Z)-1-(trimethylsilyl)dodec-4-en-1-yn-3-ol $(S-15)(2.84 \mathrm{~g}, 11.2 \mathrm{mmol})$ and methanol $(50 \mathrm{~mL})$. Potassium carbonate $(3.11 \mathrm{~g}, 22.4 \mathrm{mmol})$ was added, and the reaction mixture was stirred at room temperature overnight. After the reaction was finished, water $(50 \mathrm{~mL})$ was added. The solution was transferred into a separation funnel and was extracted with ethyl acetate $(3 \times 100$ $\mathrm{mL}$ ). The combined organic layers were washed with brine and dried over sodium sulfate, and volatiles were evaporated under reduced pressure. The mixture was redissolved in petroleum ether/EtOAc (9:1) and filtered through a pad of silica, using petroleum ether/ EtOAc (9:1) as eluent. The solvents were evaporated under reduced pressure, yielding $1.64 \mathrm{~g}(81 \%)$ of a yellowish oil. The NMR data agreed with the literature ${ }^{23}$ (mismatch in $[\alpha]^{20}$, see footnote 38 ).

$(R, Z)$-Dodec-4-en-1-yn-3-ol $(R-16)$. A $100 \mathrm{~mL}$ round-bottom flask was charged with $(S, Z)$-1-(trimethylsilyl)dodec-4-en-1-yn-3-ol $(R-14)(2.84 \mathrm{~g}, 11.2 \mathrm{mmol})$ and methanol $(50 \mathrm{~mL})$. Potassium carbonate $(3.11 \mathrm{~g}, 22.4 \mathrm{mmol})$ was added, and the reaction mixture was stirred at room temperature overnight. After the reaction was completed, water $(50 \mathrm{~mL})$ was added. The reaction solution was transferred into a separation funnel and extracted with ethyl acetate (3 $\times 100 \mathrm{~mL}$ ). The combined organic layers were washed with brine and dried over sodium sulfate, and volatiles were evaporated under reduced pressure. The mixture was redissolved in petroleum ether/ EtOAc (9:1) and filtered through a pad of silica, using petroleum ether/EtOAc (9:1) as eluent. The solvents were evaporated under reduced pressure, yielding 1.72 (85\%) of $R-16$ as a yellowish oil, for which its NMR data agreed with literature values. ${ }^{23}$ Material was used as such for the next step.

$(R, Z)$-1-Bromododec-4-en-1-yn-3-ol ( $R$-17). ( $R, Z)$-Dodec-4-en1 -yn-3-ol $(R-16)(700 \mathrm{mg}, 3.88 \mathrm{mmol})$ was dissolved in acetone $(15$ $\mathrm{mL})$; then silver nitrate $(49 \mathrm{mg}, 0.29 \mathrm{mmol})$ and $N$-bromosuccinimide $(759 \mathrm{mg}, 4.27 \mathrm{mmol}$ ) were added, and the reaction mixture was stirred for $2 \mathrm{~h}$ at room temperature. After the reaction was finished, the solution was cooled to $0{ }^{\circ} \mathrm{C}$, and $8 \mathrm{~mL}$ of water was added. The resulting mixture was stirred for $10 \mathrm{~min}$ and then extracted with diethyl ether $(3 \times 40 \mathrm{~mL})$. The combined organic layers were washed with brine $(20 \mathrm{~mL})$ and dried over sodium sulfate, and the volatiles were evaporated under reduced pressure, yielding $814 \mathrm{mg}(81 \%)$ of $R$ 17 as a colorless oil. The resulting crude material was obtained with satisfactory purity, and it was used as such for the next step without further purification. Its spectroscopic data agreed with literature values. $^{26}$

(S,Z)-1-Bromododec-4-en-1-yn-3-ol (S-17). ( $S, Z)$-Dodec-4-en1-yn-3-ol ( $S$-16) $(700 \mathrm{mg}, 3.88 \mathrm{mmol})$ was dissolved in acetone (15 $\mathrm{mL}$ ); then silver nitrate $(49 \mathrm{mg}, 0.29 \mathrm{mmol})$ and $N$-bromosuccinimide ( $759 \mathrm{mg}, 4.27 \mathrm{mmol}$ ) were added, and the reaction mixture was stirred for $2 \mathrm{~h}$ at room temperature. After the reaction was completed, the solution was cooled to $0{ }^{\circ} \mathrm{C}$, and $8 \mathrm{~mL}$ of water was added. The resulting mixture was stirred for $10 \mathrm{~min}$ and then extracted with diethyl ether $(3 \times 40 \mathrm{~mL})$. The combined organic layers were washed with brine $(20 \mathrm{~mL})$ and dried over sodium sulfate, and the volatiles were evaporated under reduced pressure, yielding $774 \mathrm{mg}(77 \%)$ of $S$ 17 as a colorless oil. The resulting crude material was obtained with satisfactory purity, and it was used as such for the next step without further purification. Its spectroscopic data agreed with literature values. ${ }^{27,29}$

Cadiot-Chodkiewidz Coupling: General Procedure. A Wheaton vial was charged with hydroxyl amine hydrochloride (27.8 $\mathrm{mg}, 0.4 \mathrm{mmol}$ ), copper chloride ( $5 \mathrm{mg}, 0.05 \mathrm{mmol})$, a $70 \%$ aqueous solution of ethylamine $(1 \mathrm{~mL}), \mathrm{H}_{2} \mathrm{O}(0.33 \mathrm{~mL})$, and $\mathrm{MeOH}(3.65$ $\mathrm{mL})$. The atmosphere was exchanged for argon, and the mixture cooled to $0{ }^{\circ} \mathrm{C}$. (R)- or (S)-tert-Butyldimethyl(pent-1-en-4-yn-3yloxy)silane $(10)$ (491 mg, $2.5 \mathrm{mmol})$ was dissolved in methanol (1.1 $\mathrm{mL})$ and added to the catalytic system. Then, $(S, Z)$ - or $(R, Z)-1$ bromododec-4-en-1-yn-3-ol (17) (295 mg, $1 \mathrm{mmol})$ was dissolved in $1.1 \mathrm{~mL}$ of methanol and added into the reaction mixture. The reaction mixture was stirred for $1 \mathrm{~h}$ at $0{ }^{\circ} \mathrm{C}$, and, after the reaction was completed, it was quenched with saturated ammonium chloride (4 $\mathrm{mL})$ and extracted with diethyl ether $(3 \times 10 \mathrm{~mL})$. The combined organic layers were washed with brine $(20 \mathrm{~mL})$ and dried over sodium sulfate, and solvents were evaporated under reduced pressure at room temperature. The product was purified by column chromatography using silica as a stationary phase and petroleum ether/EtOAc (95:5) as an eluent.

(E)-3-(4-((tert-Butyldimethylsilyl)oxy)-3-methoxyphenyl)acrylic Acid (19). trans-Ferulic acid (18) $(291 \mathrm{mg}, 1.5 \mathrm{mmol}$ ) and imidazole (1 g, $15 \mathrm{mmol}$ ) were dissolved in $9 \mathrm{~mL}$ of dry dimethylformamide (DMF). The mixture was cooled to $0{ }^{\circ} \mathrm{C}$, and TBSCl $(1.83 \mathrm{~g}, 12.4 \mathrm{mmol})$ was added. The ice bath was removed, and the resulting mixture was stirred at room temperature overnight. Then, the reaction was quenched with water $(10 \mathrm{~mL})$, the layers were separated, and the aqueous phase was extracted with $\mathrm{CH}_{2} \mathrm{Cl}_{2}(2 \times 10$ $\mathrm{mL})$. The combined organic layers were washed with brine $(15 \mathrm{~mL})$, dried over sodium sulfate, and filtered. The mixture was concentrated at reduced pressure. The resulting residue was passed through a pad of silica, using $\mathrm{CH}_{2} \mathrm{Cl}_{2}$ as an eluent. The solvent was distilled off under reduced pressure, affording 19 in $67 \%$ yield as a colorless solid. The spectroscopic data agreed with literature values. ${ }^{39}$

(3R,8S,Z)-3-((tert-Butyldimethylsilyl)oxy)heptadeca-1,9diene-4,6-diyn-8-ol $(3 R, 8 S-20)$. This was prepared according to the general procedure described above and obtained as a colorless oil in $66 \%\left(247 \mathrm{mg}\right.$ ) yield: $R_{f} 0.31$ (petroleum ether/EtOAc, 9:1); $[\alpha]^{25}$ $+208.2\left(c\right.$ 1.0, $\left.\mathrm{CHCl}_{3}\right)$; ${ }^{1} \mathrm{H}$ NMR $\left(200 \mathrm{MHz}, \mathrm{CDCl}_{3}\right) \delta 5.94-5.78$ $(1 \mathrm{H}, \mathrm{m}), 5.68-5.47(2 \mathrm{H}, \mathrm{m}), 5.43-5.33(1 \mathrm{H}, \mathrm{dt}, J=17.0 \mathrm{~Hz}, J=1.4$ $\mathrm{Hz}), 5.22-5.14(2 \mathrm{H}, \mathrm{m}), 4.93(1 \mathrm{H}, \mathrm{d}, J=4.9 \mathrm{~Hz}), 2.16-2.06(2 \mathrm{H}, \mathrm{q}$, $J=6.8 \mathrm{~Hz}), 1.84(1 \mathrm{H}, \mathrm{d}, J=5.3 \mathrm{~Hz}), 1.42-1.27(10 \mathrm{H}, \mathrm{m}), 0.91$ 
$(12 \mathrm{H}, \mathrm{s}), 0.14(3 \mathrm{H}, \mathrm{s}), 0.12(3 \mathrm{H}, \mathrm{s}) ;{ }^{13} \mathrm{C} \mathrm{NMR}\left(50 \mathrm{MHz}, \mathrm{CDCl}_{3}\right) \delta$ 136.8, 134.7, 127.9, 115.8, 79.5, 79.3, 69.4, 69.2, 64.2, 58.8, 31.9, 29.4, $29.3,29.3,27.8,25.9,22.8,18.4,14.2,-4.5,-4.8$; HRMS $\mathrm{m} / \mathrm{z}$ $397.2536[\mathrm{M}+\mathrm{Na}]$ (calcd for $\mathrm{C}_{23} \mathrm{H}_{38} \mathrm{O}_{2} \mathrm{SiNa}$, 397.2539).

General Procedure for Steglich Esterification Using EDCl. To a mixture of 3-methoxy-4-(tert-butyldimethylsilyl)oxycinnamic acid (19) (52 mg, $0.17 \mathrm{mmol}$ ), DMAP (16 mg, $0.13 \mathrm{mmol}$ ), and 3((tert-butyldimethylsilyl)oxy)heptadeca-1,9-diene-4,6-diyn-8-ol (20) $(50 \mathrm{mg}, 0.13 \mathrm{mmol})$ in dry $\mathrm{CH}_{2} \mathrm{Cl}_{2}(1.2 \mathrm{~mL})$ was added EDCI $\mathrm{HCl}(33 \mathrm{mg}, 0.17 \mathrm{mmol})$ under positive argon pressure at $0{ }^{\circ} \mathrm{C}$. The reaction vessel was sealed, and the mixture was allowed to warm to room temperature. After the reaction was completed (TLC), the mixture was cooled with an ice bath and $2 \mathrm{~N} \mathrm{HCl}(1.2 \mathrm{~mL})$ was added dropwise. The mixture was extracted with $\mathrm{CH}_{2} \mathrm{Cl}_{2}(3 \times 2 \mathrm{~mL})$, the combined organic mixtures were washed with brine $(5 \mathrm{~mL})$ and dried over sodium sulfate, and the solution was passed through a pad of Celite. Volatiles were evaporated at reduced pressure at room temperature. Products were purified by column chromatography using silica gel and petroleum ether/EtOAc (95:5).

(E)-(3R,8S,Z)-3-((tert-Butyldimethylsilyl)oxy)hexadeca-1,9dien-4,6-diyn-8-yl-3-(4-((tert-butyldimethylsilyl)oxy)-3methoxyphenyl)acrylate $(3 R, 8 S-21)$. This was prepared according to the general procedure described above and isolated as a colorless oil in $81 \%(70 \mathrm{mg})$ yield: $R_{f} 0.57$ (petroleum ether/EtOAc, 9:1); $[\alpha]_{\mathrm{D}}^{25}+91.8\left(c 0.25, \mathrm{CHCl}_{3}\right) ;{ }^{1} \mathrm{H}$ NMR $\left(200 \mathrm{MHz}, \mathrm{CDCl}_{3}\right) \delta 7.65$ $(1 \mathrm{H}, \mathrm{d}, J=16.0 \mathrm{~Hz}), 7.03-7.00(2 \mathrm{H}, \mathrm{m}), 6.84(1 \mathrm{H}, \mathrm{d}, J=8.8 \mathrm{~Hz})$, 6.33-6.25 (2H, m), 5.94-5.76 (1H, m), 5.72-5.50 (2H, m), 5.43$5.33(1 \mathrm{H}, \mathrm{dt}, J=16.8 \mathrm{~Hz}, J=1.2 \mathrm{~Hz}), 5.19-5.13(1 \mathrm{H}, \mathrm{dt}, J=10.0 \mathrm{~Hz}$, $J=1.2 \mathrm{~Hz}), 4.93(1 \mathrm{H}, \mathrm{d}, J=4.9 \mathrm{~Hz}), 3.83(3 \mathrm{H}, \mathrm{s}), 2.20(2 \mathrm{H}, \mathrm{q}, J=$ $6.8 \mathrm{~Hz}), 1.39-1.26(10 \mathrm{H}, \mathrm{m}), 0.99(9 \mathrm{H}, \mathrm{s}), 0.91-0.83(12 \mathrm{H}, \mathrm{m})$, $0.17(6 \mathrm{H}, \mathrm{s}), 0.14(3 \mathrm{H}, \mathrm{s}), 0.12(3 \mathrm{H}, \mathrm{s}) ;{ }^{13} \mathrm{C}$ NMR $(100 \mathrm{MHz}$, $\left.\mathrm{CDCl}_{3}\right) \delta 165.8,151.3,147.9,146.1,136.8,136.5,128.3,124.3,122.6$, $121.2,115.8,115.1,111.0,79.6,76.3,69.7,69.4,64.1,60.2,55.6,32.0$, 29.3, 29.3, 28.1, 25.9, 25.8, 22.8, 18.6, 18.4, 14.2, -4.8, -4.5; HRMS $\mathrm{m} / z 687.3893[\mathrm{M}+\mathrm{Na}]$ (calcd for $\mathrm{C}_{39} \mathrm{H}_{60} \mathrm{O}_{5} \mathrm{Si}_{2} \mathrm{Na}, 687.3877$ ).

General Procedure for Global Deprotection. To a solution of $21(50 \mathrm{mg}, 0.075 \mathrm{mmol})$ in THF $(0.4 \mathrm{~mL})$ was added dropwise HF. pyridine (70:30 mixture, $97.5 \mu \mathrm{L}, 50$ equiv of $\mathrm{HF}$ ) at $0{ }^{\circ} \mathrm{C}$. The mixture was stirred at room temperature. After the reaction was completed (TLC), the mixture was cooled with an ice bath and a saturated aqueous $\mathrm{NaHCO}_{3}$ solution $(\sim 1 \mathrm{~mL})$ was added. The mixture was extracted with ether $(3 \times 2 \mathrm{~mL})$, and the combined organic layers were washed with brine, dried over sodium sulfate, and filtered. Volatiles were evaporated under reduced pressure at room temperature. The product was purified with column chromatography with silica gel and petroleum ether/EtOAc (4:1).

$(3 R, 8 S)$-Notoincisol A $(3 R, 8 S-1)$. This was prepared according to the general procedure and isolated as a colorless oil in $83 \%(29 \mathrm{mg})$ yield: $R_{f}=0.57$ (petroleum ether/EtOAc, 9:1); $[\alpha]^{20}{ }_{\mathrm{D}}+87.7$ (c 0.09 , $\mathrm{MeOH}) ;{ }^{1} \mathrm{H}$ NMR $\left(400 \mathrm{MHz}, \mathrm{CDCl}_{3}\right) \delta 7.66-7.63(1 \mathrm{H}, \mathrm{d}, J=15.9$ $\mathrm{Hz}), 7.08-7.06(1 \mathrm{H}, \mathrm{dd}, J=8.2 \mathrm{~Hz}, J=1.8 \mathrm{~Hz}), 7.03-7.02(1 \mathrm{H}, \mathrm{d}, J$ $=1.8 \mathrm{~Hz}), 6.92-6.91(1 \mathrm{H}, \mathrm{d}, J=8.2 \mathrm{~Hz}), 6.29-6.27(2 \mathrm{H}, \mathrm{m}), 5.96-$ $5.90(1 \mathrm{H}, \mathrm{ddd}, J=17.1, \mathrm{~Hz}, J=10.2 \mathrm{~Hz}, J=5.1 \mathrm{~Hz}), 5.89(1 \mathrm{H}, \mathrm{s})$, $5.72-5.68(1 \mathrm{H}, \mathrm{dt}, J=10.7, \mathrm{~Hz}, J=7.5 \mathrm{~Hz}), 5.54(1 \mathrm{H}, \mathrm{t}, J=9.7 \mathrm{~Hz})$, $5.49-5.46(1 \mathrm{H}, \mathrm{d}, J=17.1 \mathrm{~Hz}), 5.27-5.25(1 \mathrm{H}, \mathrm{dt}, J=10.2 \mathrm{~Hz}, J=$ $1.1 \mathrm{~Hz}), 3.92(3 \mathrm{H}, \mathrm{s}), 4.94-4.93(1 \mathrm{H}, \mathrm{t}, J=5.1 \mathrm{~Hz}), 2.21-2.17(2 \mathrm{H}$, q, $J=7.5 \mathrm{~Hz}), 1.97-1.96(1 \mathrm{H}, \mathrm{d}, J=6.4 \mathrm{~Hz}), 1.43-1.35(2 \mathrm{H}, \mathrm{m})$, $1.29-1.25(8 \mathrm{H}, \mathrm{s}), 0.87-0.85(3 \mathrm{H}, \mathrm{t}, J=7.1 \mathrm{~Hz},) ;{ }^{13} \mathrm{C}$ NMR $(50$ $\left.\mathrm{MHz}, \mathrm{CDCl}_{3}\right) \delta 165.8,148.3,146.9,146.2,136.7,135.8,126.9,124.0$, $123.5,114.8,114.6,109.4,78.5,77.0,70.4,69.3,63.6,60.1,56.1,32.0$, 29.3, 28.1, 22.8, 14.3; HRMS $m / z 459.2150[\mathrm{M}+\mathrm{Na}]$ (calcd for $\left.\mathrm{C}_{27} \mathrm{H}_{32} \mathrm{O}_{5} \mathrm{SiNa}, 459.2147\right)$.

Molecular Docking. The ligands were constructed using ChemDraw 15 Professional (PerkinElmer, Inc.) and a Pipeline Pilot 8 (Dassault Systemes, Inc.) protocol translating .cdx into .sd files. Docking was performed with GOLD version $5.2^{40-42}$ employing the ChemPLP scoring function. The X-ray crystal structure of human PPAR $\gamma$ bound to two molecules of magnolol (PDB entry $3 r 5 n$ ), ${ }^{33}$ a natural product and partial agonist of the receptor, was selected for the docking calculations. The protonation state of His 323 was set to
NE2, and the water molecule no. 35 was set to "toggle and spin". This means that the docking algorithm can choose to turn, keep, or delete this water molecule depending on which setting gives the best docking results. For the docking, both magnolol ligands were removed from the binding site and used to define the binding site location. Docking settings were validated by redocking of magnolol into the receptor. Magnolol was docked at the location of either one or the other cocrystallized magnolol binding sites with an average RMSD of 0.823 $\AA$. The docking poses of compounds $3 R, 8 S-\mathbf{1}, 3 R, 8 R-\mathbf{1}, 3 S, 8 S-\mathbf{1}$, and 3S,8R-1 were analyzed using LigandScout 4.2.1 (Inte:Ligand GmbH, Vienna, Austria).

PPAR $\gamma$ Reporter Gene Transactivation. PPAR $\gamma$ luciferase reporter gene transactivation experiments were performed using HEK293 cells (ATCC, Manassas, VA, USA). HEK293 cells were maintained in Dulbecco's modified Eagle's medium (DMEM) supplemented with $10 \%$ fetal bovine serum, $2 \mathrm{mM}$ glutamine, 100 $\mathrm{U} / \mathrm{mL}$ benzylpenicillin, and $100 \mu \mathrm{g} / \mathrm{mL}$ streptomycin. Then, $6 \times 10^{6}$ cells were seeded in $20 \mathrm{~cm}$ dishes, cultured for $18 \mathrm{~h}$, and transfected with $6 \mu \mathrm{g}$ of a full-length human PPAR $\gamma$ expression plasmid, $6 \mu \mathrm{g}$ of a firefly luciferase reporter plasmid containing a PPAR response element, and $3 \mu \mathrm{g}$ of pEGFP-N1 (Clontech, Mountain View, CA, USA) as internal control. After $6 \mathrm{~h}$ of transfection, cells were reseeded in 96-well plates $\left(4 \times 10^{4}\right.$ cells/well $)$ in serum-free DMEM supplemented with $2 \mathrm{mM}$ glutamine. Reseeded cells were treated with $0.1,0.3,1,3,10$, and $30 \mu \mathrm{M}$ of each test compound dissolved in DMSO and were then incubated for $18 \mathrm{~h}$. After cell lysis, luciferase activity and EGFP fluorescence were quantified on a GeniosPro plate reader (Tecan, Grödig, Austria). The ratio of luminescence units to fluorescence units was calculated to account for differences in cell number or transfection efficiency. Results are expressed as fold induction compared to the solvent DMSO (0.1\%). Pioglitazone (5 $\mu \mathrm{M})$ was used as positive control.

Statistical analysis was performed using Prism software (ver. 4.03; GraphPad Software Inc., San Diego, CA, USA). To calculate the $\mathrm{EC}_{50}$ values, data were curve fitted and nonlinear transformed using a sigmoidal dose response with variable slope.

Resazurin Conversion Assay. Cell viability was detected by employing a resazurin conversion assay. This method is based on the reduction of resazurin into resorufin by redox equivalents resulting from cellular metabolism. The fluorescence signal of resorufin produced in viable cells is proportional to the number of cells and can be used as a measure for cell viability or cytotoxicity. HEK293 cells were seeded in 96-well plates at a density of $4 \times 10^{4}$ cells/well and grown overnight. Cells were then treated with each test compound $(0.3,1,3,10$, and $30 \mu \mathrm{M})$ for $24 \mathrm{~h}$ and incubated for 4 $\mathrm{h}$ with resazurin solution $(10 \mu \mathrm{g} / \mathrm{mL}$ in PBS $)$ at $37^{\circ} \mathrm{C}$. Fluorescence was quantified in a plate reader using a $535 \mathrm{~nm}$ excitation/590 nm emission filter set.

$\mathrm{GABA}_{\mathrm{A}}$ Electrophysiology. All four notoincisol A isomers were investigated on receptor subtypes $\alpha 1 \beta 3$ and $\alpha 1 \beta 2 \gamma 2$. Oocytes were prepared and injected with mRNA mixtures of the subunits, and receptor expressing oocytes were evaluated as described previously. ${ }^{18}$ Initial preliminary screenings of all four compounds at different GABA concentrations (EC3-5, EC20, EC50, and EC80) and at compound concentrations of 1 and $10 \mu \mathrm{M}$ diluted into measurement buffer were performed. Moderate enhancement of GABA-elicited currents was observed for $\alpha 1 \beta 3$ as well as for $\alpha 1 \beta 2 \gamma 2$. This effect was strongest at EC3-5, consistent with an allosteric modulatory action of the compounds. Further measurements were thus performed at EC3-5 by coapplying GABA+ compound. In $\alpha 1 \beta 3$ receptors the resulting currents did not reach maximum strength even at longer $(120 \mathrm{~s})$ recording times. $\alpha 1 \beta 3$-specific kinetic properties could be a reason for this phenomenon. In an effort to obtain the maximum enhancement of the GABA EC3-5 current, further measurements with preapplication of the compound for up to $105 \mathrm{~s}$ were performed until saturation was reached. Direct effects were tested by applying compound without GABA. Data were recorded and evaluated using standard procedures as described previously. ${ }^{18}$ 


\section{ASSOCIATED CONTENT}

\section{(S Supporting Information}

The Supporting Information is available free of charge on the ACS Publications website at DOI: 10.1021/acs.jnatprod.8b00439.

$$
\text { Additional information (PDF) }
$$

\section{AUTHOR INFORMATION}

\section{Corresponding Author}

*Tel: ++43 158801 15420. Fax: +43 158801 15499. E-mail: mmihovil@poptuwien.ac.at (M. D. Mihovilovic).

\section{ORCID}

Rudolf Bauer: 0000-0002-0057-5547

Verena M. Dirsch: 0000-0002-9261-5293

Michael Schnürch: 0000-0003-2946-9294

Marko D. Mihovilovic: 0000-0002-5438-8368

\section{Notes}

The authors declare no competing financial interest.

\section{ACKNOWLEDGMENTS}

This project was in part supported by the Austrian Science Fund (FWF): S10710 and S10704 (NFN "Drugs from Nature Targeting Inflammation"). L.R. is a fellow of the graduate school program Molecular Drug Targets MolTag (FWF, grant no. W1232). J.P. was supported by the Austrian Science Fund FWF P 27746 to M.E. and M.S. The authors gratefully thank Dr. E. Rosenberg and Dr. L. Czollner for HRMS analysis. We thank Inte:Ligand $\mathrm{GmbH}$ for providing an academic license for LigandScout. D.S. is an Ingeborg Hochmair Professor at the University of Innsbruck.

\section{REFERENCES}

(1) Liu, X.; Kunert, O.; Blunder, M.; Fakhrudin, N.; Noha, S. M.; Malainer, C.; Schinkovitz, A.; Heiss, E. H.; Atanasov, A. G.; Kollroser, M.; Schuster, D.; Dirsch, V. M.; Bauer, R. J. Nat. Prod. 2014, 77, $2513-2521$.

(2) Azietaku, J. T.; Ma, H.; Yu, X. A.; Li, J.; Oppong, M. B.; Cao, J.; An, M.; Chang, Y. X. J. Ethnopharmacol. 2017, 202, 241-255.

(3) Christensen, L. P.; Brandt, K. J. Pharm. Biomed. Anal. 2006, 41, 683-693.

(4) Boll, P. M.; Hansen, L. Phytochemistry 1987, 26, 2955-2956.

(5) Dawid, C.; Dunemann, F.; Schwab, W.; Nothnagel, T.; Hofmann, T. J. Agric. Food Chem. 2015, 63, 9211-9222.

(6) Chen, Y.; Peng, S.; Luo, Q.; Zhang, J.; Guo, Q.; Zhang, Y.; Chai. Chem. Biodiversity 2015, 12, 474-502.

(7) Christensen, L. P. Recent Pat Food Nutr Agric. 2011, 3, 64-77.

(8) Waltenberger, B.; Atanasov, A. G.; Heiss, E. H.; Bernhard, D.; Rollinger, J. M.; Breuss, J. M.; Schuster, D.; Bauer, R.; Kopp, B.; Franz, C.; Bochkov, V.; Mihovilovic, M. D.; Dirsch, V. M.; Stuppner, H. Monatsh. Chem. 2016, 147, 479-491.

(9) Atanasov, A. G.; Waltenberger, B.; Pferschy-Wenzig, E.-M.; Linder, T.; Wawrosch, C.; Uhrin, P.; Temml, V.; Wang, L.; Schwaiger, S.; Heiss, E. H.; Rollinger, J. M.; Schuster, D.; Breuss, J. M.; Bochkov, V.; Mihovilovic, M. D.; Kopp, B.; Bauer, R.; Dirsch, V. M.; Stuppner, H. Biotechnol. Adv. 2015, 33, 1582-1614.

(10) Wang, L.; Waltenberger, B.; Pferschy-Wenzig, E. M.; Blunder, M.; Liu, X.; Malainer, C.; Blazevic, T.; Schwaiger, S.; Rollinger, J. M.; Heiss, E. H.; Schuster, D.; Kopp, B.; Bauer, R.; Stuppner, H.; Dirsch, V. M.; Atanasov, A. G. Biochem. Pharmacol. 2014, 92, 73-89.

(11) Jiang, C.; Ting, A. T.; Seed, B. Nature 1998, 391, 82-86.

(12) Ricote, M.; Li, A. C.; Willson, T. M.; Kelly, C. J.; Glass, C. K. Nature 1998, 391, 79-82.
(13) Su, C. G.; Wen, X.; Bailey, S. T.; Jiang, W.; Rangwala, S. M.; Keilbaugh, S. A.; Flanigan, A.; Murthy, S.; Lazar, M. A.; Wu, G. D. J. Clin. Invest. 1999, 104, 383-389.

(14) Schep, L. J.; Slaughter, R. J.; Becket, G.; Beasley, D. M. G. Clin. Toxicol. 2009, 47, 270-278.

(15) Czyzewska, M. M.; Chrobok, L.; Kania, A.; Jatczak, M.; Pollastro, F.; Appendino, G.; Mozrzymas, J. W. J. Nat. Prod. 2014, 77, 2671-2677.

(16) Wyrembek, P.; Negri, R.; Kaczor, P.; Czyzewska, M.; Appendino, G.; Mozrzymas, J. W. J. Nat. Prod. 2012, 75, 610-616.

(17) Hintersteiner, J.; Haider, M.; Luger, D.; Schwarzer, C.; Reznicek, G.; Jaeger, W.; Khom, S.; Mihovilovic, M. D.; Hering, S. Eur. J. Pharmacol. 2014, 735, 123-131.

(18) Rycek, L.; Puthenkalam, R.; Schnuerch, M.; Ernst, M.; Mihovilovic, M. D. Bioorg. Med. Chem. Lett. 2014, 25, 400-403.

(19) Schoeffmann, A.; Wimmer, L.; Goldmann, D.; Khom, S.; Hintersteiner, J.; Baburin, I.; Schwarz, T.; Hintersteininger, M.; Pakfeifer, P.; Oufir, M.; Hamburger, M.; Erker, T.; Ecker, G. F.; Mihovilovic, M. D.; Hering, S. J. Med. Chem. 2014, 57, 5602-5619.

(20) Varagic, Z.; Wimmer, L.; Schnuerch, M.; Mihovilovic, M. D.; Huang, S.; Rallapalli, S.; Cook, J. M.; Mirheydari, P.; Ecker, G. F.; Sieghart, W.; Ernst, M. Br. J. Pharmacol. 2013, 169, 371-383.

(21) Wimmer, L.; Schoenbauer, D.; Pakfeifer, P.; Schoeffmann, A.; Khom, S.; Hering, S.; Mihovilovic, M. D. Org. Biomol. Chem. 2014, 13, 990-994.

(22) Baur, R.; Gertsch, J.; Sigel, E. PeerJ 2013, 1e149.

(23) Olsen, R. W.; Sieghart, W. Neuropharmacology 2008, 56, 141148.

(24) Sieghart, W.; Ernst, M. Curr. Med. Chem.: Cent. Nerv. Syst. Agents 2005, 5, 217-242.

(25) Li, Z.-Y.; Wang, M.; Bian, Q.-H.; Zheng, B.; Mao, J.-Y.; Li, S.N.; Liu, S.-Z.; Wang, M.-A.; Zhong, J.-C.; Guo, H.-C. Chem. - Eur. J. 2011, 17, 5782-5786.

(26) Mann, T. J.; Speed, A. W. H.; Schrock, R. R.; Hoveyda, A. H. Angew. Chem., Int. Ed. 2013, 52, 8395-8400.

(27) Sabitha, G.; Bhaskar, V.; Reddy, C. S.; Yadav, J. S. Synthesis 2008, 1, 115-121.

(28) Schmiech, L.; Alayrac, C.; Witulski, B.; Hofmann, T. J. Agric. Food Chem. 2009, 57, 11030-11040.

(29) Tamura, S.; Ohno, T.; Hattori, Y.; Murakami, N. Tetrahedron Lett. 2010, 51, 1523-1525.

(30) Cadiot, P.; Chodkiewicz, W. Couplings of acetylenes. In Chemistry of Acetylenes; Marcel Dekker: New York, 1969; pp 597-647

(31) Brown, C. A.; Ahuja, V. K. J. Org. Chem. 1973, 38, 2226-2230.

(32) Atanasov, A. G.; Blunder, M.; Fakhrudin, N.; Liu, X.; Noha, S. M.; Malainer, C.; Kramer, M. P.; Cocic, A.; Kunert, O.; Schinkovitz, A.; Heiss, E. H.; Schuster, D.; Dirsch, V. M.; Bauer, R. PLoS One 2013, 22, e61755.

(33) Zhang, H.; Xu, X.; Chen, L.; Chen, J.; Hu, L.; Jiang, H.; Xu, S. PLoS One 2011, 6, e28253.

(34) Sigel, E.; Baur, R.; Rácz, I.; Marazzi, J.; Smart, T. G.; Zimmer, A.; Gertsch, J. Proc. Natl. Acad. Sci. U. S. A. 2011, 108, 18150-18155.

(35) Baur, R.; Kielar, M.; Richter, L.; Ernst, M.; Ecker, G. F.; Sigel, E. J. Neurochem. 2013, 126, 29-36.

(36) Wang, L.; Liu, R.; Lv, C.; Ou, J.; Liu, F.; Liu, S.; Wang, M.; Zhong, J. Tetrahedron: Asymmetry 2013, 24, 173-177.

(37) Young, D. G. J.; Burlison, J. A.; Peters, U. J. Org. Chem. 2003, 68, 3494-3497.

(38) There was a mismatch of the value measured for the compound $S$-16 synthesized by us $\left([\alpha]^{25}-118.6\left(c 1.0, \mathrm{CHCl}_{3}\right)\right)$ and the value reported in the literature $\left([\alpha]^{25}+64.97\left(c 1.0, \mathrm{CHCl}_{3}\right)\right)$ (ref 26). The reason we believe the correct value is the one measured herein is based on several arguments that (a) the enantiomeric compound $R$ 16, synthesized for the first time, has a value very close to that measured by us for $S-16$ but with the opposite sign, $[\alpha]^{25}{ }_{D}+118.1(c$ $1.0, \mathrm{CHCl}_{3}$ ); (b) further modification of $S-16$ led to a compound known in the literature (S-17). A match was found in the comparison of the value measured herein and by others (ref 27). 
(39) Rattanangkool, E.; Kittikhunnatham, P.; Damsud, T.; Wacharasindhu, S.; Phuwapraisirisan, P. Eur. J. Med. Chem. 2013, 66, 296-304.

(40) Cambridge Crystallographic Data Centre, UK; www.ccdc.cam. ac.uk/solutions/csd-discovery/components/gold/.

(41) Jones, G.; Willett, P.; Glen, R. C. J. Mol. Biol. 1995, 245, 43-53.

(42) Jones, G.; Willett, P.; Glen, R. C. J. Mol. Biol. 1997, 267, 727748. 